
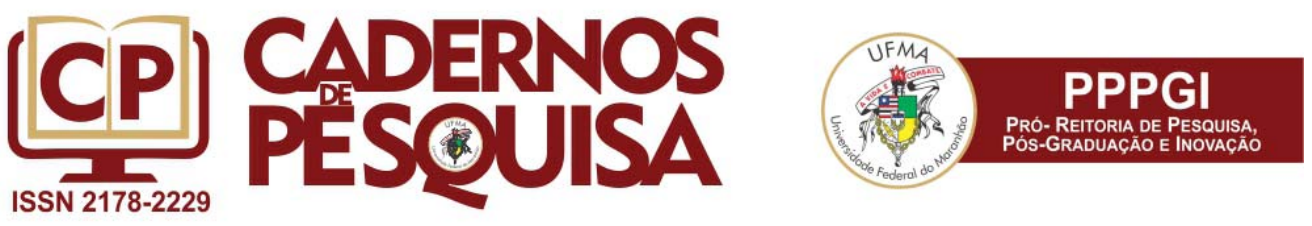

\title{
AS PERCEPÇÕES DE PROFESSORES DE CIÊNCIAS SOBRE A SUA PRÁTICA PEDAGÓGICA NAS ESCOLAS DO CAMPO
}

\author{
THE PERCEPTIONS OF SCIENCE TEACHERS ON THEIR \\ PEDAGOGICAL PRACTICE IN RURAL SCHOOLS
}

\section{LAS PERCEPCIONES DE LOS PROFESORES DE CIENCIAS SOBRE SU PRÁCTICA PEDAGÓGICA EN LAS ESCUELAS DEL CAMPO}

\author{
Claudia Regina Machado Kliemann \\ Mestre em Educação pela Universidade Estadual do Oeste do Paraná (UNIOESTE) \\ Toledo-PR, Brasil. \\ claudiakliemann@yahoo.com.br \\ Dulce Maria Strieder \\ Doutora em Educação pela Universidade de São Paulo - USP \\ Cascavel-PR, Brasil. \\ dulce.strieder@unioeste.br
}

\section{Resumo}

O ensino de Ciências busca um ensino significativo, histórico e contextualizado aos estudantes, conforme Krasilchik (2000), condições consideradas basilares também para a Educação do Campo. Assim, o ensino de Ciências das escolas do campo, oportunizado aos estudantes, deve se apresentar de forma dialógica, no qual as problematizações estabelecidas sejam contextualizadas com a realidade dos estudantes, mobilizando os seus conhecimentos prévios, articulando os conceitos e estabelecendo os conhecimentos científicos, de acordo com Freire (1977), Delizoicov, Angotti e Pernambuco (2009). Como guia do processo, o professor orienta o caminho do processo dialógico do ensino de Ciências nas escolas do campo. Nesse sentido, o artigo, resultado de pesquisa qualitativa, tem o objetivo de analisar as percepções dos professores de Ciências das escolas do campo sobre o ensino de Ciências, a sua prática pedagógica e a formação inicial e continuada desses docentes. Os dados foram coletados a partir de entrevistas individuais com os professores de Ciências das escolas estaduais do campo do município de Toledo/PR e analisados por meio da técnica da Análise de Conteúdo, de Bardin (1977). Os resultados apontam que os professores buscam assumir uma prática pedagógica diferenciada, com o intuito de aproximar os conteúdos curriculares da realidade dos estudantes. Assim, ações de caráter interno nas escolas e outras vinculadas à Secretaria de Estado da Educação precisam ser articuladas para viabilizar a efetivação da modalidade de ensino nas escolas do campo.

Palavras-chave: Ensino de Ciências. Educação do Campo. Docentes.

\begin{abstract}
Science education provides meaningful, historical and contextualized teaching to students, according to Krasilchik (2000), conditions considered to be the basis for Rural Education. Thus, the Science teaching of the rural schools should be presented in a dialogical, in which the established problematizations are contextualized with the reality of the students, disturbing their prior knowledge, articulating the concepts and establishing the scientific knowledge, according to Freire (1977), Delizoicov, Angotti and Pernambuco (2009). As a guide to the process, the teacher guides the way of the dialogical process of teaching science in the rural schools. In this way, the article, result of qualitative research, has the objective of to analyze the perceptions of the Science teachers of the rural schools about the teaching of Sciences, their pedagogical practice and the initial and continuous formation of these teachers. The data were collected from individual interviews with the teachers of Sciences of the rural state schools of the city of Toledo/PR and analyzed through the technique of Content Analysis, by Bardin (1977). The results show the teachers seek to assume a differentiated pedagogical practice with the aim of bringing curricular contents closer to students' reality.
\end{abstract}

Artigo recebido em julho 2017. Aprovado em janeiro de 2018. 
Thus, internal character of actions in schools and other linked to the State Department of Education must be coordinated to enable the realization of Rural Education in rural schools.

Keywords: Science teaching. Rural Education. Teachers.

\section{Resumen}

La enseñanza de Ciencias busca una docencia significativa, histórica y contextualizada a los estudiantes, según Krasilchik (2000), condiciones considerables basilares también para la Educación del Campo. Así, la enseñanza de Ciencias de las escuelas del campo conveniente a los estudiantes debe presentar de forma dialógica, en el cual las problematizaciones establecidas sean contextualizadas con la realidad de los alumnos, movilizando sus conocimientos previos, estructurando los conceptos y estableciendo los conocimientos científicos, de acuerdo con Freire (1977), Delizoicov, Angotti y Pernambuco (2009). Como guía del desarrollo, el profesor orienta el camino del proceso dialógico de la disciplina de Ciencias en las escuelas del campo. En ese sentido, el artículo, resultado de investigación cualitativa, tiene el objetivo de analizar las percepciones de los profesores de Ciencias de las escuelas del campo sobre la enseñanza de Ciencias, su práctica pedagógica y la formación inicial y continuada de esos docentes. Los datos fueron colectados a partir de entrevistas individuales con los profesores de Ciencias de las escuelas estaduales del campo del municipio de Toledo/PR y analizados por medio de la técnica del Analice de Contenido, de Bardin (1977). Los resultados apuntan que los profesores buscan asumir una práctica pedagógica diferenciada, con el intento de aproximar los contenidos trabajados con la realidad de los estudiantes. Así, acciones de carácter interno en las escuelas y otras vinculadas a la Secretaria del Estado de la Educación precisan ser planeada para posibilitar la realización de la modalidad de la enseñanza en las escuelas del campo.

Palabras clave: Enseñanza de Ciencias. Educación del Campo. Docentes.

\section{INTRODUÇÃO}

A educação é inerente à vivência das pessoas, pois estamos permanentemente adquirindo conhecimentos, de maneira formal, informal ou não formal. Na educação formal, o contexto escolar interfere no direcionamento do perfil da ação. Considerando a especificidade da educação no espaço rural, pode-se dizer que esta, durante muitas décadas, esteve à margem das políticas educacionais nacionais.

$\mathrm{Na}$ metade do século XX ocorreram alguns investimentos na Educação Rural, mas a oferta de ensino continuava incipiente, precária, com escassez de recursos e regida na perspectiva urbana, objetivando principalmente a fixação da população rural no campo. Em tempos posteriores, ocorreu a ressignificação da educação destinada aos sujeitos que vivem e trabalham no campo, sendo implantada a Educação do Campo nas escolas que atendem à maioria de estudantes oriundos do campo, que tem direito a uma educação no campo, considerando o direito de estudar no lugar onde vivem, e do campo, com uma educação significada a partir da sua cultura e do seu espaço (CALDART, 2002). Esta possui, assim, fundamentos diferenciados, superando a Educação Rural.

A Educação do Campo é uma modalidade de ensino da Educação Básica, implantada por meio de políticas públicas nacionais desde 2002, a qual possui documentos norteadores organizados. No estado do Paraná foram instituídas, em 2006, as Diretrizes Curriculares da Educação do Campo (DCEs da Educação do Campo), que constituem o documento norteador estadual para as escolas classificadas como escolas do campo (e não apenas escolas no campo), e a política pública foi incorporada ao sistema de ensino do estado em 2010. Atualmente está inserida no sistema educacional em espaços escolares específicos e que permeiam desde a Educação Infantil até cursos de nível superior. As escolas do campo estão estruturadas em diversas disciplinas, de acordo com a matriz curricular, entre elas o ensino de Ciências.

Este artigo tem por objetivo analisar as percepções dos professores de Ciências das escolas do campo sobre o ensino de Ciências, a prática pedagógica realizada em sala de aula e a formação inicial e continuada desses professores. 
Para isso, o artigo apresenta um panorama geral sobre o ensino de Ciências e a prática pedagógica, especialmente, nas escolas do campo, além da formação inicial e continuada ofertada aos professores de Ciências das escolas do campo. Posteriormente, é realizada a explicitação do caminho da investigação e da análise de dados de acordo com Análise de Conteúdo de Bardin (1977). Os resultados são apresentados e analisados em categorias, sendo elas: a prática pedagógica dos professores de Ciências das escolas do campo e formação inicial e continuada dos professores de Ciências das escolas do campo.

\section{O ENSINO DE CIÊNCIAS}

Na primeira metade do século XX, a ciência era apresentada aos estudantes como uma atividade neutra, que abordava o conceito apenas. Essa compreensão alterou-se e, nessa transformação, foram considerados o desenvolvimento histórico e o contexto social do estudante (KRASILCHIK, 2000), pois os estudantes e os professores de uma escola são seres sociais que crescem e se desenvolvem na e com a sociedade. É imprescindível o uso de elementos culturais e da realidade dos estudantes nos mais variados conteúdos, sendo este ensino contextualizado social, política, histórica e economicamente, com o objetivo de evidenciar um ensino de Ciências para a formação da cidadania (ASTOLFI; DEVELAY, 1990; CHASSOT, 2014).

Os autores Pozo e Crespo (2009, p. 21, grifo do autor) defendem que "[...] a ciência é um processo e não apenas um produto acumulado em forma de teorias ou modelos, e é necessário levar para os alunos esse caráter dinâmico e perecedouro dos saberes científicos", evidenciando o caráter provisório e falível, histórico e descontínuo dos acontecimentos científicos. Dessa forma, o conhecimento científico trabalhado na forma de conteúdos escolares, deve ser selecionado e organizado baseado na sua relevância sociocultural e econômica para o estudante (SILVA, 2004), sendo estabelecido um currículo original, que busca trabalhar as especificidades de forma contextualizada com a realidade dos estudantes.

É relevante destacar que o espaço escolar é o ambiente formal de discussão dos conhecimentos científicos. Entretanto, o estudante carrega consigo o conhecimento que é devido às suas experiências vividas, imbuídas de aspectos culturais. Logo, a escola é "[...] o espaço do confronto e diálogo entre os conhecimentos sistematizados e os conhecimentos do cotidiano popular" (PARANÁ, 2008, p. 23).

Conforme afirmam Astolfi e Develay (1990, p. 35, grifo do autor), "[...] toda aprendizagem vem interferir com um 'já existente' conceitual que, ainda que falso num plano científico, serve de sistema de explicação eficaz e funcional para o docente". Assim, é essencial ao professor considerar esses conceitos já existentes dos estudantes nas mediações a serem realizadas durante as aulas.

As ideias que os estudantes já possuem recebem diferentes nomeações, considerando que os diferentes estudos abrangendo o assunto, adotaram termos específicos, podendo ser denominadas como crenças, preconcepções, ideias, pontos de vista, conhecimento prévio, concepções errôneas, concepções alternativas, entre outros (BIZZO, 1998). É fundamental considerar que "[...] as características que foram atribuídas a essas ideias ou concepções variam de um autor para o outro" (POZO; CRESPO, 2009, p. 88). Além disso, são utilizados os termos "[...] senso comum, cultura primeira, concepções prévias ou alternativas, representações sociais, mundo vivido, entre outros, conforme as intenções dos estudos realizados" (DELIZOICOV; ANGOTTI; PERNAMBUCO, 2009, p. 132). Neste trabalho, nós trataremos essas ideias como conhecimentos prévios e, com o propósito de caracterizá-las, podemos considerar que:

Tudo é prático, aplicável, resulta em benefício individual imediato; as relações são perceptíveis e explicáveis, e não resultam da aplicação de qualquer método universalmente reconhecido; e ele não constitui disciplina acadêmica. Mas é visto como uma espécie de 'denominador comum daquilo que um grupo ou um povo 
coletivamente acredita, ele tem, por isso, uma vocação solidarista e transclassista'. Não se trata, portanto, de hostilizá-lo na escola. O que essa instituição deve fazer é proporcionar acesso a outras formas de conhecimento que, muitas vezes, constituem explicações alternativas - quando não frontalmente opostas - às crenças da coletividade (BIZZO, 1998, p. 21, grifo do autor).

Cada sujeito possui experiências únicas devido ao contexto cultural e social vivido, trazendo o seu significado e a sua interpretação sobre algo e o professor estará atribuindo significado ao processo de ensino e aprendizagem realizado em sua aula, ao realizá-lo de forma contextualizada.

De acordo com Bizzo (1998, p. 55, grifo do autor), quando a resposta dada pelo "[...] aluno está baseada, entre outras coisas, em sua experiência pessoal, empírica; trata-se de um argumento perceptivo", ou seja, a resposta revela as percepções que o estudante possui sobre determinado conceito relacionadas às suas experiências empíricas.

Cunha (2009, p. 28) destaca que o ato de perceber vai muito além de simplesmente descobrir e identificar estímulos internos ou externos à pessoa:

\begin{abstract}
[...] perceber é detectar, é interpretar sinais que têm origem externa ao sistema nervoso central. [...] Perceber é uma elaboração em que o alicerce são as sensações, as memórias, as vivências, as experiências e as expectativas, sejam elas inatas ou adquiridas por meio da interação com o meio. Por isso, a percepção é um processo mental seletivo, [...] selecionamos eventos e situações deixando de fora os que não nos fazem sentido.
\end{abstract}

Cada indivíduo, de acordo com o seu interesse e a sua realidade, constrói conhecimentos sobre o mundo real de forma subjetiva, que são interpretações e elaborações únicas, pois cada indivíduo formula a sua própria percepção sobre cada objeto ou fato analisado, ou seja, percebe-o de maneira única. Dessa maneira, as percepções originam posicionamentos e argumentações individualizadas frente à diversidade de enfrentamentos da vida.

Luria (2013) afirma que os processos cognitivos como a percepção, o raciocínio, a imaginação e outros, vão se reelaborando com as mudanças que ocorrem em nosso contexto de vida, pois as pessoas significam e estabelecem as percepções próprias dos conceitos.

Assim, os conhecimentos prévios podem ser considerados como os conhecimentos empíricos, experimentados anterior e exteriormente à educação formal, a serem trabalhados no decorrer do processo de ensino-aprendizagem. Já as percepções podem ser consideradas como um processo cognitivo que relaciona as experiências, as memórias e as sensações provenientes da interação com o meio, que vão se reelaborando de acordo com as vivências do sujeito, inclusive no processo educacional.

\title{
2.1 A prática pedagógica e o ensino de Ciências
}

No processo educativo formal, a aprendizagem depende em grande parte dos procedimentos didáticos definidos pelo professor. Seguindo essa perspectiva, Schnetzler (1992, p. 17) afirma que "[...] o estilo de ensino de um professor manifesta a sua concepção de educação, aprendizagem e dos conhecimentos e atividades que propicia aos seus alunos." Esse estilo, ou seja, as atitudes e os comportamentos de ensino manifestados pelo professor são decorrentes também da sua formação ambiental ${ }^{1}$, formada e reformulada durante os vários anos no quais foi estudante (CARVALHO; GIL-PÉREZ, 2011).

Segundo os autores Astolfi e Develay (1990), e Delizoicov, Angotti e Pernambuco (2009), o professor tem um papel fundamental no processo educacional e deve assumir

A formação ambiental de um professor é adquirida de forma natural, não reflexiva, devido às experiências vividas no processo educacional durante o tempo no qual foi estudante (CARVALHO; GIL-PÉREZ, 2011). 
uma postura de mediador da sua prática pedagógica. Para isso, é essencial "[...] reconhecer que esse aluno é, na verdade, o sujeito de sua aprendizagem, é quem realiza a ação [...]" (DELIZOICOV; ANGOTTI; PERNAMBUCO, 2009, p. 122).

Dessa forma, o estudante é a peça fundamental para a ocorrência do processo de ensino-aprendizagem de forma eficaz. O estudante não pode apenas ser paciente do processo educativo, mas deve ser percebido como um sujeito histórico que, além de possuir um conhecimento, é capaz de utilizá-lo para o entendimento de demais conhecimentos, inclusive para transformar a sociedade ao seu redor.

É imprescindível uma prática pedagógica de caráter dialógico, que o diálogo seja viabilizado entre as partes do processo de ensino-aprendizagem, professor e estudantes, para que o conhecimento prévio do estudante e o saber do professor sejam problematizados. Nesse sentido:

\begin{abstract}
É a apreensão do significado e interpretação dos temas por parte dos alunos que precisa estar garantida no processo didático-pedagógico, para que os significados e interpretações dados possam ser problematizados. Porém, na perspectiva de uma educação dialógica, como a proposta por Freire, os significados e interpretações dos temas pelos alunos não serão os únicos que terão de ser apreendidos e problematizados; aqueles de que o professor é portador também precisam estar presentes no processo educativo. $\mathrm{O}$ diálogo a ser realizado refere-se aos conhecimentos que ambos os sujeitos da educação, aluno e professor, detêm a respeito do tema, objeto de estudo e compreensão (DELIZOICOV; ANGOTTI; PERNAMBUCO, 2009, p. 193, grifo do autor).
\end{abstract}

O diálogo entre os conhecimentos do mediador e dos estudantes tem por objetivo "[...] a problematização do próprio conhecimento em sua indiscutível reação com a realidade concreta na qual se gera e sobre a qual incide, para melhor compreendê-la, explicá-la, transformá-la" (FREIRE, 1977, p. 52), pois cada sujeito possui experiências únicas relacionadas ao seu contexto. Assim, não se tem como propósito apresentar as respostas aos estudantes, mas desenvolver questionamentos, a fim de contextualizar e significar a realidade destes.

A problematização se baseia na realidade vivida pelos estudantes e tem como pretensão inicial mobilizar os conhecimentos prévios, para posteriormente estabelecer os problemas e nortear o aprendizado dos conhecimentos científicos (DELIZOICOV; ANGOTTI; PERNAMBUCO, 2009).

Ainda sobre a arte de questionar, de problematizar, de desafiar, Freire (1977, p. 54) relata que "Na verdade, nenhum pensador, como nenhum cientista, elaborou seu pensamento ou sistematizou seu saber científico sem ter sido problematizado, desafiado. [...] o desafio é fundamental à constituição do saber."

É essencial que o professor seja cuidadoso ao estabelecer uma prática pedagógica dialógica em sala de aula, pois "[...] é difícil desligar-se das primeiras impressões, [...]" (ASTOLFI; DEVELAY, 1990, p. 25), com o objetivo de não restringir ou limitar a abordagem pedagógica às experiências de vida dos estudantes. É fundamental salientar que a problematização contextualizada é o início do processo dialógico e da sistematização dos conhecimentos científicos estabelecida pelo professor (PARANÁ, 2008).

Assim, na prática pedagógica, espera-se "[...] que sejam exploradas tanto a dimensão dialógica do ato educativo como a dimensão problematizadora do ato gnosiológico" (DELIZOICOV; ANGOTTI; PERNAMBUCO, 2009, p. 195, grifo do autor), do ato cognitivo, do conhecimento, da aprendizagem sobre o estudo desenvolvido.

O estudante que participa efetivamente do processo educativo, assimilando e aprendendo os conhecimentos científicos da sistematização realizada, de forma geral, apresenta maior possibilidade de argumentar e de se posicionar sobre determinado assunto, visto que, na sua vida escolar foi desenvolvida a sua capacidade de análise e a criticidade, predicados indispensáveis à vivência em sociedade para qualquer cidadão. 


\subsection{O ensino de Ciências nas escolas do campo}

A disciplina de Ciências é entendida como um "[...] conjunto de elementos integradores que constitui o Universo em toda sua complexidade [...] como tempo, espaço, matéria, movimento, força, campo, energia e vida" (PARANÁ, 2008, p. 40), que, relacionados, originam os fenômenos da natureza, interpretados e modificados pelo homem. E, para o ensino de Ciências nas escolas do campo, se busca o entendimento dos conhecimentos científicos a partir da investigação da natureza e do contexto vivido pelos estudantes, sendo indispensável trabalhar esta questão de forma substancial.

O processo de contextualização pode ser significado de variadas formas, mas concordamos com a ideia de contextualização apresentada por Wartha, Silva e Bejarano, (2013, p. 90), como "[...] um entendimento mais complexo do que a simples exemplificação do cotidiano ou mera apresentação superficial de contextos sem uma problematização que de fato provoque a busca de entendimentos sobre os temas de estudo."

Sendo assim, é essencial no meio educacional, principalmente no ensino de Ciências das escolas do campo, considerar o contexto cultural vivido pelo estudante, pois um ensino significativo, contextualizado, é imprescindível para que o estudante se sinta de fato comprometido com o processo educacional (SANTOS; SCHNETZLER, 2003).

É fundamental para o desenvolvimento da contextualização que o professor enfrente "[...] a tentação de dar respostas prontas, mesmo que detenha a informação exata, oferecendo novas perguntas em seu lugar, que levassem os alunos a buscar a informação com maior orientação e acompanhamento" (BIZZO, 1998, p. 50), pois se o professor responde ao seu questionamento no início da contextualização, então não há mais motivo para continuar o diálogo, pois a relação a ser estabelecida não pode mais ser construída (ASTOLFI; DEVELAY, 1990).

Quando não há proximidade entre o conteúdo ensinado e a vivência dos estudantes, o ensino e, especialmente, o ensino de Ciências das escolas do campo, é visto como pouco significativo pelos estudantes. Por isso, a dialogicidade da prática pedagógica deve ser efetivada fundamentalmente com o uso de elementos culturais e do contexto dos estudantes, com o propósito de mediar o conteúdo curricular e as relações contextualizadoras. O aprendizado, o saber, bem como todos os processos mentais, tudo é influenciado e formado a partir do contexto vivido (LURIA, 2013), objetivando um aprendizado mais argumentativo e significativo para o estudante.

Diga-se, no entanto, que, para desenvolver o processo educativo de forma contextualizada, "[...] rompendo com práticas educativas já estabelecidas historicamente, vai [se] promovendo as transformações necessárias" (DELIZOICOV; ANGOTTI; PERNAMBUCO, 2009, p. 196) e estabelecendo relações a fim de que essas transformações sejam inseridas e validadas no processo de ensino, ressaltando que "[...] não é apenas o professor que deve modificar sua forma de ensinar, mas que uma série de ordenamentos na escola e na comunidade devem ser considerados [...]" (BIZZO, 1998 , p. 33). É essencial que todos os profissionais das escolas do campo trabalhem focados nos objetivos estabelecidos conjuntamente, na busca de uma maior qualidade de ensino.

Nesse sentido, Brick et al. (2014) assinalam que, em um ambiente de aprendizagem da Educação do Campo, os estudos são realizados de melhor maneira se organizados conforme uma investigação temática. Essa organização envolve todas as disciplinas em torno de um projeto único, interdisciplinar. Dessa maneira, Caldart (2011, p. 109) afirma que: "A ideia de interdisciplinaridade surge ligada à finalidade de corrigir possíveis erros e a esterilidade acarretada por uma ciência excessivamente compartimentada e sem comunicação entre si". Além disso, se torna essencial a interdisciplinaridade para compreender e transformar uma realidade complexa (BRITTO; SILVA, 2015). 
De acordo com Britto (2011), e concordando com esse entendimento, para desenvolver essa proposta de trabalho é fundamental dedicação intensa na preparação das atividades, considerando dois fatores que não podem ser omitidos e podem ser limitantes se não forem superados: a formação dos professores em áreas específicas do conhecimento e suas percepções assinaladas pelo contexto urbano. Porém, para superar essas dificuldades e promover uma transformação do processo educativo é essencial professores que trabalhem por isso, que planejam de forma coletiva a fim de que ocorra a interdisciplinaridade, que estejam motivados à mudança, e que ocorra uma efetiva formação continuada.

O processo educativo de uma escola do campo deve passar por constante avaliação, formulação e reformulação, organizando e reorganizando o currículo escolar e as ações desenvolvidas (BRICK et al., 2014), pois o currículo não é neutro e a organização dele, assim como a ciência, não está pronto e acabado, mas em constante transformação.

\section{A FORMAÇÃO INICIAL E CONTINUADA PARA EDUCADORES DO CAMPO}

É imprescindível ao professor saber e saber fazer, pois "[...] uma falta de conhecimentos científicos constitui a principal dificuldade para que os professores afetados se envolvam em atividades inovadoras" (CARVALHO; GIL-PÉREZ, 2011, p. 22, grifo do autor), pois o professor se torna um mero transmissor dos conteúdos curriculares já elaborados, como no formato do ensino tradicional, e se adequa ao modelo de escola estabelecido, sem questionar o processo educativo e o contexto concebido.

Entretanto, assim como o professor precisa saber e saber fazer em sala de aula com seus estudantes, o formador também precisa cumprir essas condições, caso contrário a formação perde o seu sentido de aperfeiçoamento da prática pedagógica e passa a ser um protocolo a ser cumprido e "[...] de maneira geral, não há preparação formal para o formador [...]" (MIZUKAMI, 2005/2006, s.p.).

O parágrafo único do artigo 12 da Resolução n $1-\mathrm{CNE} / \mathrm{CEB} / \mathrm{MEC}^{2}$, que institui as Diretrizes Operacionais para a Educação Básica nas Escolas do Campo, estabelece que serão desenvolvidas "[...] políticas de formação inicial e continuada, habilitando todos os professores leigos e promovendo o aperfeiçoamento permanente dos docentes" (BRASIL, 2002, p. 2). Entretanto, devido à contemporaneidade da Educação do Campo há pouco material à disposição no ensino de Ciências (BRICK et al., 2014) e em todas as áreas do currículo.

No estado do Paraná, a instrução conjunta n 001/2010 - SEED/SUED/SUDE ${ }^{3}$, instrui que cada departamento possui as suas atribuições em relação à implantação da Educação do Campo em algumas escolas estaduais e, em relação à formação dos professores dessas escolas, cabe ao Núcleo Regional de Educação (NRE):

\footnotetext{
[...] V. realizar ações interinstitucionais como: fóruns, encontros, seminários, entre outros e/ou contribuir com a realização das mesmas, objetivando a disseminação das Diretrizes Curriculares da Educação do Campo ou visando contribuir no fortalecimento e na consolidação da Política Pública de Educação do Campo, voltadas à qualificação do atendimento das populações rurais nas Escolas do Campo; [...] (PARANÁ, 2010a, s.p., grifo nosso).
}

Ainda sobre a formação continuada dos professores, as DCEs da Educação do Campo do Estado do Paraná trazem reflexões e destacam que: "É preciso que os cursos de formação de professores ousem na reflexão sobre as formas de superar a visão disciplinar da educação [...]" (PARANÁ, 2006, p. 40).

Dessa forma, é possível perceber que a formação continuada sobre a Educação do Campo ainda está em construção e são pretendidas para as escolas do campo transformações curriculares baseadas em um trabalho interdisciplinar, superando essa

\footnotetext{
2 Resolução do Conselho Nacional de Educação (CNE), da Câmara da Educação Básica (CEB) e do Ministério da Educação (MEC).

3 Instrução conjunta da Secretaria de Estado da Educação (SEED), da Superintendência da Educação (SUED) e a Superintendência de Desenvolvimento Educacional (SUDE).
} 
visão disciplinar consolidada na educação. Entretanto, essa organização almejada é inerente ao trabalho desenvolvido pelos profissionais da educação de cada escola do campo. Para isso, é imprescindível o apoio e o empenho dos órgãos estaduais, em especial SEED e NRE, a fim de proporcionar o suporte técnico e possibilitar momentos para a sistematização de ideias entre os profissionais da educação, e a organização de um projeto político-pedagógico para a escola do campo que busca a interdisciplinaridade, a contextualização e a efetividade do processo dialógico.

\section{O CAMINHO DA PESQUISA, A CONSTRUÇÃO DO BANCO DE DADOS E OS PROCEDIMENTOS DE ANÁLISE}

A investigação realizada está pautada na abordagem qualitativa que pode ser comparada a "[...] um quadro que vai ganhando forma à medida que se recolhem e examinam partes. O processo de análise dos dados é como um funil: as coisas estão abertas de início (ou no topo) e vão-se tornando mais fechadas e específicas no extremo" (BOGDAN; BIKLEN, 1994, p. 50). Para a realização da investigação foram consideradas todas as 10 escolas do campo localizadas no município de Toledo/PR e os seus respectivos professores de Ciências, totalizando 12 entrevistados.

As escolas estaduais do campo de Toledo, possuíam 1166 estudantes matriculados no ano de 2015, ano no qual a pesquisa foi realizada, considerando as matrículas do ensino regular e das atividades complementares. Esses ambientes educacionais mais retirados do centro urbano, que por meio da Resolução $n^{\circ} 4.783 / 2010 / S E E D / P R$, passaram a ser chamadas escolas do campo (PARANÁ, 2010c), contemplam o Ensino Fundamental Anos Finais da Educação Básica, e um deles compreende também 0 Ensino Médio.

A tessitura desse artigo se utiliza de dados referentes a uma pesquisa mais abrangente, a qual teve o projeto de pesquisa enviado para apreciação do Conselho de Ética em Pesquisa envolvendo Seres Humanos (CEP) da Universidade Estadual do Oeste do Paraná (UNIOESTE) e teve aprovação ${ }^{4}$ em 30 de julho de 2015.

$\mathrm{Na}$ construção do seu banco de dados foi promovida a reunião e organização das informações e dos dados coletados nas entrevistas semiestruturadas, a partir de um questionário semiestruturado, considerando as entrevistas como "[...] conversas com finalidades [...]" (MINAYO, 2010, p. 64, grifo do autor).

As entrevistas foram áudio-gravadas e transcritas literalmente, reproduzindo fielmente as falas correspondentes. Para garantir o anonimato dos sujeitos respondentes, as entrevistas foram codificadas, sendo $\mathrm{P}$ (P1 até P12) para o(a) professor(a) de Ciências e E para a entrevistadora/pesquisadora. Além disso, a natureza das falas é apresentada no registro, como pausas, entonação de voz e outros, isso considerado como fundamental por Thompson (1992) e Carvalho (2011).

Os registros das falas dos respondentes da pesquisa foram analisados empregando a técnica de Análise de Conteúdo (BARDIN, 1977) para o tratamento das informações coletadas. Nesse sentido, seguimos as etapas: a) pré-análise: organização e sistematização do material que contém os dados e leitura flutuante; b) exploração do material e tratamento dos resultados: codificação e tratamento dos dados brutos, determinação das unidades de significação e categorização; c) inferência e interpretação das categorias emergentes da Análise de Conteúdo realizada.

\section{ANÁLISE E DISCUSSÃO DOS RESULTADOS}

É realizada uma abordagem qualitativa para analisar as percepções dos professores de Ciências das escolas estaduais do campo do município de Toledo/PR. Os resultados estão organizados em categorias e subcategorias que emergiram da Análise de Conteúdo realizada. Neste trabalho serão destacadas duas categorias, das quais emergiram subcategorias, conforme pode ser observado no quadro a seguir.

\footnotetext{
4 Certificado de Apresentação para Apreciação Ética (CAAE): 47078415.1.0000.0107.
} 
Quadro 1 - Categorias e subcategorias emergentes das unidades analisadas

\begin{tabular}{|l|l|l|}
\hline \multicolumn{1}{|c|}{ CATEGORIAS } & \multicolumn{1}{|c|}{ SUBCATEGORIAS } & \multicolumn{1}{c|}{ UNIDADES DE SIGNIFICAÇÃO } \\
\hline \multirow{2}{*}{$\begin{array}{l}\text { 1. A prática pedagógica dos professores de } \\
\text { Ciências das escolas do campo }\end{array}$} & 1.1 Caracterização da prática pedagógica & P1, P2, P3, P4, P5, P6, P7, P8, P9, P10, P11 e P12 \\
\cline { 2 - 3 } & 1.2 Ensino de Ciências & P1, P2, P3, P4, P5, P6, P7, P8, P9, P10, P11 e P12 \\
\hline \multirow{2}{*}{$\begin{array}{l}\text { 2. Formação inicial e continuada dos } \\
\text { professores de Ciências das escolas do } \\
\text { campo }\end{array}$} & $\begin{array}{l}\text { 2.1 Abordagem da Educação do Campo na } \\
\text { formação inicial }\end{array}$ & P1, P2, P3, P4, P5, P6, P7, P8, P9, P10, P11 e P12 \\
\cline { 2 - 3 } & 2.2 Formação continuada ofertada & P1, P2, P3, P4, P5, P6, P7, P8, P9, P10, P11 e P12 \\
\hline
\end{tabular}

Fonte: Elaborado pelas autoras.

A categorização realizada foi interpretada e analisada à luz de diferentes referenciais teóricos relacionados à Educação do Campo e ao ensino de Ciências, significando os resultados obtidos durante a investigação. Concomitantemente à análise são apresentados alguns fragmentos das entrevistas, excertos que se configuram como exemplos das unidades de significação encontradas, com reprodução fiel das falas dos entrevistados, juntamente com as categorias e subcategorias para representar as percepções apresentadas pelos professores de Ciências e, posteriormente, as inferências primordiais à sua discussão.

5.1 Categoria 1: A prática pedagógica dos professores de Ciências das escolas do campo

São destacados excertos que trazem alguns fatores apontados como relevantes sobre a prática pedagógica e sobre o ensino de Ciências nas escolas do campo.

\subsubsection{Subcategoria 1.1: Caracterização da prática pedagógica}

Nos fragmentos destacados são apresentados alguns aspectos apontados pelos professores sobre a sua prática pedagógica, sobre o trabalho desenvolvido nas escolas do campo, o seu conhecimento sobre a realidade do campo, o seu compromisso com os conteúdos curriculares e outros detalhes:

Eu tenho meu padrão fixo aqui desde 2006... eu poderia ter levado o meu padrão pra cidade... [...] eu quero ficar... exatamente por esse diferencial tá da família na escola... [...] a gente tem que buscar essa cultura do campo [...] a maioria dos conhecimentos que eu tenho... que eu passo para os meus alunos é porque eu tenho e morei no campo... então eu sei... porque eu tenho a prática... [...]. (P2).

[...] eles conhecem muito mais algumas coisas sobre:: plantas e animais... eles têm exemplos mais práticos... [...] é importante você conhecer o máximo possível para entender o seu aluno também... a realidade:.: como ele vive e como ele vê o mundo... [...] poderia ser trabalhada:: a questão da interdisciplinaridade [...] na prática não tem nada que diferencie a Educação do Campo à educação da cidade... quem faz a diferenciação é o próprio professor [...]tento fazer algumas coisas de forma diferente mas eu tenho o meu compromisso com o meu planejamento [...] tento trazer exemplos para a realidade deles [...]planejar aula que eu tenho que adaptar algo eu tenho muito mais trabalho do que utilizar aquela aula pronta [...]. (P6).

Exige bastante do professor... a gente tem que tá voltando todo o conteúdo para a realidade deles... [...] é uma realidade totalmente diferente da minha... Eu ia pro campo... eu ia pro sítio nossa... três ou quatro vezes na vida... [...] então fico meio:: perdida mesmo... [...] a gente precisa conhecer os alunos... conhecer a comunidade... [...] é uma coisa que:: que me deixa bastante feliz porque eu aprendo muito com eles também... [...]. (P7).

[...] e aí a gente vem e dá só:: o conteúdo:: normal:: e tenta relacionar de uma forma muito superficial e aí não é o diferencial... [...] Deveria ser trabalhado diferente pra eles terem aqui no campo:.: terem uma aplicabilidade melhor... do conteúdo com a prática deles lá na granja... na plantação... é que eu ainda não consigo oferecer isso... 
[...] a gente tem a prateleira ali Educação do Campo né... e raramente a gente pega né porque aí eu tô preocupada em preparar conteúdo né... então eu não tive tempo ainda... (P9).

Até hoje nunca foi repassado pra gente que a gente teria que fazer algo bem diferenciado com eles e tudo mais... Mas:: eu tenho essa consciência e eu faço meio que por conta... [...] eu morava no interior... eu conheço um pouco [...] se eu pudesse fixar padrão nessas escolas de interior... eu não trocava mais [...] essa questão:: da educação... do comprometimento que eu percebo dos alunos... e dos pais... é muito legal... [...]. (P11).

[...] eu tenho um conhecimento bastante grande da:: da comunidade... dos alunos... Muitos pais dos alunos de hoje já foram meus alunos... [...] a questão da interdisciplinaridade e que hoje pelo fato de termos professores vindos dos mais diversos recantos... esse momento talvez não aconteça... esse andar junto... esse formar um cidadão mais consciente num todo... [...] sempre procurei ilustrar as minhas aulas com temas atuais né... fugindo um pouco talvez do livro... [...]. (P12).

Um aspecto destacado pelos professores P6 e P9 se refere ao fato do quão consideram relevante que o professor conheça o seu estudante e a comunidade na qual a escola está inserida, a sua cultura, como declara P2, ou seja, o contexto no qual o estudante está inserido para possibilitar "[...] uma aplicabilidade melhor... do conteúdo com a prática deles lá [...]", conforme expressa P9. Os professores P6, P7 e P9 comentam sobre os conhecimentos prévios dos estudantes e a tentativa em relacioná-los com as temáticas abordadas em sala de aula.

De acordo com Freire (2015, p. 32, grifo do autor), ensinar exige respeito aos saberes dos estudantes. Então: "Por que não estabelecer uma 'intimidade' entre os saberes curriculares fundamentais aos alunos e a experiência social que eles têm como indivíduos?". Essa indagação pode ser respondida parcialmente utilizando algumas relações realizadas na subcategoria 3.1, quando Silva (2004) afirma que se faz necessária uma reorganização curricular para que seja possível uma problematização da realidade, a fim de estabelecer a contextualização e significação dos assuntos tratados em sala de aula.

Também são realizados esforços pelos professores para aproximar os estudantes do conteúdo, na tentativa de "trazer exemplos", "ilustrar as aulas", como apontado claramente pelos professores P6 e P12, pois os professores têm consciência dessa necessidade, mas, conforme enfatiza P9: "[...] tenta relacionar de uma forma muito superficial e aí não é o diferencial...". Uma preocupação apontada por Caldart, Stedile e Daros (2015, p. 102, grifo do autor) está relacionada às práticas pedagógicas realizadas em sala de aula que, na tentativa de vincular o ensino à realidade são simplificadas de forma que se configuram, muitas vezes, como a "[...] 'tematização da realidade'5, ou mesmo da simples 'ilustração de conteúdos' confundidas com o conhecimento dos fenômenos reais, que é o que afinal buscamos."

$\mathrm{Na}$ busca de evitar esses equívocos e continuando a responder à indagação anterior, Freire (2015) afirma que os professores precisam saber ou estarem abertos à realidade dos seus estudantes, caracterizando como essencial que o professor conheça o contexto dos estudantes e os elementos culturais da sua realidade, para proporcionar a realização de um processo dialógico significativo, com problematizações pertinentes, relacionando os seus conhecimentos prévios, que aguçam a curiosidade e possibilitam articulações necessárias para a construção do conhecimento científico. Nesse sentido, Arroyo, Caldart e Molina (2004) pedem atenção para que os estudantes sejam tratados como sujeitos reais, históricos e singulares no decorrer do processo educativo.

\footnotetext{
De acordo com Caldart, Stedile e Daros (2015, p. 102), uma fragilidade destacada "[...] está na base tanto das referências de conteúdos de ensino assumidas pelas escolas, como das próprias tentativas pedagógicas de vincular ensino e realidade [...] [caracterizando um] estudo frio, desistoricizado e fragmentado de conteúdos [que] não leva ao conhecimento." Uma tentativa de relacionar conteúdos e realidade dos estudantes, mas que se caracteriza pelo distanciamento e pela superficialidade.
} 
Ainda sobre conhecer o contexto dos estudantes, os professores P2, P11 e P12 declaram ter a prática do campo por já ter residido ou residir no campo. Se o professor possui sua vivência relacionada ao espaço rural, pode, mais facilmente, aliar o seu conhecimento informal adquirido no seu cotidiano ao processo de ensino-aprendizagem do conhecimento científico, se comparado com um professor que teve contato apenas com o meio urbano, e para o professor que não tem esse convívio com o campo, essa aproximação torna-se mais complexa. Cabe enfatizar, no entanto, que o contexto rural é diverso e dinâmico, um contexto de muitas particularidades, conforme destaca Chauí (2000), sobre a diversidade existente entre culturas distintas, a pluralidade cultural.

Dessa forma, cada escola do campo possui as suas particularidades, e o seu contexto social específico, assim como os estudantes possuem os seus conhecimentos, a sua cultura e seus valores. Logo, práticas vivenciadas pelos professores podem não ser similares às desenvolvidas por seus estudantes. Considerando esse aspecto, 0 professor P12 conhece o contexto escolar de seus estudantes, pois reside há 44 anos no distrito em que trabalha.

Os professores P6 e P7 declaram que planejar aulas contextualizadas para os estudantes torna-se muito mais trabalhoso, pois isso exige mais dedicação do professor. Além disso, as professoras P6 e P9 manifestaram o seu compromisso e a sua preocupação em cumprir com a preparação dos conteúdos curriculares que constam no planejamento e, para isso, trazemos a crítica de Freire (1977, p. 53, grifo do autor):

\begin{abstract}
[...] não há tempo a perder, visto que existe um programa que deve ser cumprido. $\mathrm{E}$, uma vez mais, em nome do tempo que não se deve perder, o que se faz é perder tempo, alienando-se a juventude com um tipo de pensamento formalista, com narrações quase sempre exclusivamente verbalistas. Narrações cujo conteúdo 'dado' deve ser passivamente recebido e memorizado para depois ser repetido.
\end{abstract}

Se o processo educativo for realizado de forma dialógica, fazendo uso de problematizações contextualizadas para mobilizar os conhecimentos prévios dos estudantes, há possibilidade de que um tempo maior seja empregado para isso. Em contrapartida, conteúdos que eram trabalhados de forma fragmentada e descontextualizados serão significados, pois a prática pedagógica, tal como "[...] a Escola, muito mais que ser vista como reprodutora do conhecimento, deve ser pensada nas suas amplas possibilidades de fazer uma educação crítica" (CHASSOT, 2014, p. 214).

A interdisciplinaridade, mencionada pelos professores P6 e P12, é um ponto considerado de muita relevância para a Educação do Campo e converge com o exposto anteriormente. Eles declaram que ela poderia ser trabalhada, mas é algo que não está sendo efetivado e o professor P12 acrescenta: "[...] hoje pelo fato de termos professores vindos dos mais diversos recantos... esse momento talvez não aconteça... esse andar junto [...]." Assim, a interdisciplinaridade é percebida pelos professores como uma alternativa para trabalhar da melhor maneira o conteúdo de Ciências das escolas do campo e de acordo com as Diretrizes Curriculares da Educação do Campo do Estado do Paraná (PARANÁ, 2006, p. 40): "O diálogo e o encontro com o outro na escola, na comunidade, são centrais na elaboração de uma prática interdisciplinar".

De acordo com Streck, Redin e Zitkoski (2008, p. 236), a interdisciplinaridade é uma prática "[...] estabelecida, por Freire, como requisito para uma visão da realidade nas perspectivas da unidade e da totalidade do real." Da mesma forma, um trabalho interdisciplinar ocorre pela valorização das disciplinas "[...] na potencialidade de, em conjunto e articuladas pelo coletivo docente, interpretar a realidade em suas diversas dimensões, não mais de forma fragmentada como a disciplinarização dos conteúdos" (BRITTO; SILVA, 2015, p. 773). Dessa maneira, o diálogo é oportunizado, a fim de articular conhecimentos e ações em um trabalho conjunto. Além disso, de acordo com Britto (2014, p. 68), 
[...] a interdisciplinaridade está em conformidade com a realização de práticas educativas comprometidas socialmente e politicamente, na qual o conhecimento sistematizado está a serviço do processo educativo, ou seja, a seleção de conhecimentos a serem trabalhados emerge do diálogo com a realidade e a problematização de suas contradições e conflitos.

Entretanto, essa interdisciplinaridade muito relevante à efetivação da Educação do Campo e que "poderia" estar acontecendo, como declarado pela professora P6, não vem sendo estabelecida porque não estão ocorrendo momentos de diálogo entre os professores, pois, para apresentar um trabalho interdisciplinar, é preciso planejar coletivamente, o que significa reunir o coletivo de professores nos quais a articulação dos conteúdos e atividades podem ser pensados e elaborados conjuntamente, para a sua posterior implementação no espaço escolar como prática pedagógica.

É fundamental, à análise da prática pedagógica, destacar um fragmento das declarações da professora P7: "[...] me encantou assim sabe... é uma coisa que.: que me deixa bastante feliz porque eu aprendo muito com eles também...". "A atividade docente de que a discente não se separa é uma experiência alegre por natureza" (FREIRE, 2015, p. 139) e a prática pedagógica será mais favorecida e, de certa forma, enriquecida se houver uma relação de proximidade entre professor e estudante, pois "A afetividade não se acha excluída da cognoscibilidade", trata-se de um incremento, de considerável importância, à experiência pedagógica. Além disso, os professores P2 e P11 manifestam a sua vontade de permanecer trabalhando na escola do campo, com ela se identificando e estreitando relações de afetividade.

\begin{abstract}
Assim temos o entendimento de que a ação educativa se concretiza pelo diálogo, mediado pela problematização da realidade perpassada por contradições que clamam para serem desveladas e compreendidas pel@ ${ }^{6}$ estudantes das escolas do campo, para que possam tomar consciência e estabelecer novos olhares sobre a realidade no/do campo, fortalecidos por uma compreensão mais ampliada das transformações sociais para além do contexto local (BRITTO; SILVA, 2015, p. 770).
\end{abstract}

Diversas são as mudanças necessárias à prática pedagógica dos professores das escolas estaduais do campo para torná-la uma prática contextualizada, dialógica e interdisciplinar. Ocorre, porém, que os incentivos para que isso se concretize são insuficientes, como revela o professor P11: "Até hoje nunca foi repassado pra gente que a gente teria que fazer algo bem diferenciado com eles e tudo mais... Mas:: eu tenho essa consciência e eu faço meio que por conta...". Se o professor não tiver a sensibilidade e o interesse de mudar, de "adequar" o conteúdo trabalhado à realidade do estudante, mesmo sendo conhecedor do contexto dos estudantes de forma limitada, as aulas de Ciências das escolas do campo serão as mesmas ou muito semelhantes às da escola urbana.

Dessa forma, na busca pela melhoria do processo de ensino e aprendizagem, são indispensáveis incentivos ao professor, principalmente no sentido de formação continuada específica. Além disso, é primordial, nesse processo de estruturação da modalidade de ensino da Educação do Campo, a intermediação da direção escolar e equipe pedagógica, que, vinculados ao professor, possam estabelecer, juntamente com o Núcleo Regional de Educação, o suporte indispensável à prática pedagógica do professor.

\title{
5.1.2 Subcategoria 1.2: Ensino de Ciências
}

A seguir são apresentadas algumas percepções dos professores sobre aspectos considerados relevantes do ensino de Ciências das escolas do campo, a caracterização

\footnotetext{
6 De acordo com Britto (2013, p. 108): "O símbolo @ é utilizado como artifício nas palavras que devem ser lidas no sentido de evidenciar a importância de alterarmos a tendência sexista de manter todas as palavras no masculino, mesmo em situações em que o universo é majoritariamente feminino."
} 
das aulas de Ciências e, ainda, algumas abordagens diferenciadas realizadas pelos professores:

[...] que ele consiga aplicar esse conhecimento na sua vida diária... no seu dia a dia... [...] Esses dias eles trouxeram uma casca de cobra... outro dia eles fizeram um minhocário... [...] mudar a realidade onde ele vive pra ser um cidadão mais consciente do seu papel na sociedade e que ele possa ajudar as pessoas da sua comunidade ajudar... Enfim todo um contexto pra gente ter uma qualidade de vida melhor né... [...]. (P1).

Há 15 dias atrás estava trabalhando sobre minhocas eu saí rapidinho fui na horta arranquei a minhoca e trouxe ((risos)) a minhoca pra sala de aula... [...] incentivar o aluno para ele permanecer no campo... [...] A Ciência é o que está acontecendo AGORA tá... hoje tá... o que eu disse hoje amanhã pode não ser mais... [...]. (P2).

[...] acredito que os mesmos assuntos que possam ser trabalhados na cidade... são os assuntos trabalhados na escola do campo... [...]. (P5).

[...] a gente tenta fazer um pouco dos dois né... dar foco pra aquilo que é do dia a dia deles mas também trazer coisas do MUNDO né... [...] a disciplina de Ciências está aí pra isso... pra implantar isso nos alunos né... deixá-los mais.: mais conscientes da realidade que eles vivem [...]. (P7).

[...] talvez precisasse ser de uma maneira mais interdisciplinar né... porque ele ajuda a interpretar tudo o que o aluno passa no cotidiano [...] ele se forma um indivíduo mais crítico né... a gente favorece a criticidade... ele não aceita as coisas de maneira tão:: tão morosa assim né... tão passiva... [...] coisas que eles veem na realidade deles né... trazem pra mim... [...] a entrada da primavera... Então o professor de Artes confeccionou as mandalas que são os elementos da natureza:: [...] Éh:: eu fiz o filtro dos sonhos com eles representando as relações ecológicas... as frutas representando a alimentação saudável... éh:: fizemos também uma parte de Educação Ambiental né com reflexões sobre o futuro:: [...]. (P9).

Acho que não só para as escolas do campo... o ensino de Ciências ele dá:: tenta dar ao cidadão a noção... não só decorar palavras novas e difíceis... mas que eles saibam ah:: levar este conhecimento para o dia a dia... [...] enfim que eles se sintam motivados a pesquisar... a procurar e quem sabe... ter um mundo... um planeta que os possa sustentar no futuro... (P12).

Nos fragmentos selecionados são relatadas algumas atividades e outras abordagens diferenciadas nas aulas, mas restritas ao ensino de Ciências, não sendo de caráter interdisciplinar, elaboradas por iniciativa do professor no seu planejamento de aula. Conforme discutido na subcategoria anterior e apresentado no relato dos professores, essas práticas pedagógicas podem ser caracterizadas como por uma "ilustração dos conteúdos"7 ou "tematização da realidade" (CALDART; STEDILE; DAROS, 2015).

A professora P9 declara que o ensino nas escolas do campo precisaria ser de forma mais interdisciplinar. Uma tentativa de realizar uma abordagem interdisciplinar foi apresentada pela professora quando relata a ação pedagógica realizada para a entrada da primavera, na qual relata a participação de outro professor e uma variedade de atividades e reflexões articuladas. Em uma ação interdisciplinar, o trabalho das disciplinas em conjunto traz a diversidade de conhecimentos e os entrelaçamentos destes, com o intuito de interpretar a realidade (BRITTO; SILVA, 2015), características essenciais para essa abordagem diferenciada reivindicada nas escolas do campo, mas precisam ser proporcionadas condições para que ações nesse sentido sejam viabilizadas.

Diferentemente dos outros professores, a professora P5 considera "[...] que os mesmos assuntos que possam ser trabalhados na cidade... são os assuntos trabalhados na escola do campo... [...]", pois não há necessidade em diferenciar as aulas de

\footnotetext{
A "ilustração dos conteúdos" e a "tematização da realidade" são "[...] tentativas pedagógicas de vincular ensino e realidade", (CALDART; STEDILE; DAROS, 2015, p. 102), mas inapropriadas, pois simplificam essa discussão de tal maneira que traz prejuízos a essência do conhecimento trabalhado.
} 
Ciências para o contexto urbano e do campo. Dessa forma, a professora desconsidera a necessidade de contextualização das temáticas trabalhadas e, conforme já discutido, a contextualização é necessária ao processo de ensino-aprendizagem, fundamental para dar sentido ao estudo das mais variadas temáticas, pois uma abordagem pedagógica descontextualizada é uma prática a ser superada nas escolas do campo (ARROYO; CALDART; MOLINA, 2004). Cabe salientar que, em qualquer escola, o ensino de Ciências deve ser contextualizado e significativo para os estudantes (KRASILCHIK, 2000; PARANÁ, 2008).

Assim, ao ensino de Ciências de uma maneira geral não é admitido que seja realizado um ensino neutro e a-histórico, distante da realidade do cenário atual (KRASILCHIK, 2000). Da mesma forma, é destacada a relevância de abordagens que trabalham com a realidade dos estudantes, contextualizando-o social, política e economicamente, a fim de estabelecer um ensino de Ciências voltado à formação cidadã do estudante (ASTOLFI; DEVELAY, 1990; CHASSOT, 2014).

Os professores analisados, de maneira geral, destacam como relevantes as abordagens que trabalham temáticas que estejam relacionadas ao campo, à sua vida diária, para possibilitar, além da significação do conteúdo, uma formação cidadã, com pensamento crítico em relação às ações observadas e realizadas no decorrer do dia a dia, zelando pelo meio onde vive. Entretanto, continua sendo trabalhada uma educação que oportuniza ao estudante a possibilidade de ampliar o seu olhar para contextos diversificados.

Devido à realidade da região toledana, justifica-se que as temáticas de ensino estejam relacionadas à produção leiteira, à suinocultura, à piscicultura, à avicultura, à agricultura, à utilização de agrotóxicos, à produção orgânica, entre outras formas de produção e atividades, características de cada comunidade escolar, além do entendimento e de conhecer as características, a estrutura e o funcionamento do agronegócio, modo de produção e exploração da terra utilizado na contemporaneidade. Sendo assim, compete "[...] aos professores e alunos, num processo investigativo, chegar à indicação de temas significativos para determinada comunidade local" (PARANÁ, 2006, p. 40), a fim de que o processo educativo realizado na escola do campo esteja relacionado com a realidade dos seus estudantes.

Ainda sobre a criticidade dos estudantes, Chassot (2014, p. 55) afirma que a responsabilidade maior dos professores ao "[...] ensinar Ciência é procurar que nossos alunos e alunas se transformem, com o ensino que fazemos, em homens e mulheres mais críticos". Além disso, compete a nós, professores , "[...] formar os futuros cidadãos para que eles sejam aprendizes mais flexíveis, eficientes e autônomos, dotando-os de capacidades de aprendizagem e não só de conhecimentos ou saberes específicos [...]" (POZO; CRESPO, 2009, p. 25), na intenção de interpretar e compreender a sua realidade, para transformar o mundo em que vivem em um espaço melhor, com maior qualidade de vida e mais sustentável, como afirmam os professores $\mathrm{P} 1$ e P12, respectivamente.

O professor P2 afirma que "A ciência é o que está acontecendo AGORA tá... hoje tá... o que eu disse hoje amanhã pode não ser mais... [...]", destacando como essencial o fato das constantes atualizações devido ao caráter dinâmico e provisório dos conhecimentos científicos, caracterizando-os como um processo (POZO; CRESPO, 2009).

Sobre as perspectivas apontadas e discutidas, Britto (2013, p. 111) afirma que:

[...] pensar o $\mathrm{ECN}^{8}$ e a educação científica, sob sua relevância cultural, social e econômica, por meio de sua historicidade, é bastante pertinente, indo ao encontro da crescente necessidade de que a ciência seja conhecida e aproveitada por tod@s

Ensino de Ciências da Natureza. 
- reconhecendo a diversidade dos sujeitos -, não ficando restrita aos cientistas e/ou pesquisador@s no âmbito acadêmico.

Portanto, práticas contextualizadas são identificadas e destacadas como relevantes pelos professores e algumas ações isoladas são apontadas nas suas declarações. Mesmo as abordagens limitadas, de certa forma, contribuem para formar a criticidade do estudante, refletindo em contribuição para a sociedade na qual esse estudante vive, tem e cria suas relações históricas, econômicas, sociais e culturais. Mesmo em um ambiente no qual os professores apresentam poucos conhecimentos específicos da Educação do Campo e falta de incentivos que promovam a reunião dos pares e a articulação da interdisciplinaridade da prática pedagógica, nas tentativas de contextualizar o conteúdo e de abordá-lo de forma interdisciplinar, podem surgir iniciativas valiosas no desenvolvimento do processo educativo.

5.2 Categoria 2: Formação inicial e continuada dos professores de Ciências das escolas do campo

Essa categoria discute sobre a formação inicial e continuada dos professores de Ciências das escolas estaduais do campo do município de Toledo/PR e a abordagem da Educação do Campo relacionada o ensino de Ciências.

\subsubsection{Subcategoria 2.1: Abordagem da Educação do Campo na formação inicial}

Nesta subcategoria são apresentados abaixo alguns fragmentos sobre a relevância em abordar a temática da Educação do Campo na formação acadêmica do professor entrevistado.

[...] faz muito tempo ((risos)) e naquela época ainda não se falava em ensino diferenciado pra essas escolas... E uma tendência mais atual... [...] o professor sabendo que são realidades diferentes ele vai poder abordar e poder optar também... (P1).

Não existia... faz muito tempo essa graduação ((risos))... [...] a Educação do Campo mesmo que seja uma disciplina em um dos anos tá... tem que ser inserido em todas as licenciaturas tá... [...] Mas em muitas universidades eu acredito que não terão nem um professor habilitado para trabalhar essa disciplina lá na graduação... [...]. (P2).

[...] depois que eu terminei:: que eles começal... inseriram a Educação do Campo... [...] A faculdade me trouxe mais os conteúdos... [...] a parte prática do trabalho mesmo eu tive só quando eu comecei a trabalhar [...] Pra quem mora no interior eles tem um pouco essa noção né mas os que moram na cidade não tem essa noção de quão diferente pode ser trabalhar numa escola da cidade e trabalhar numa escola do interior... [...]. (P6).

[...] talvez tenha sido citado esse tipo de educação mas... mas também nada muito específico... [...] talvez fazer uma disciplina nova com modalidades diferenciadas em educação... aí a Educação do Campo... Educação Especial... EJA que também não é trabalhado né... [...] Acho que ter na grade é importante sim... [...]. (P9).

[...] eles tocaram assim levemente no assunto... [...] se a gente adequar o Ensino Superior pra generalizar pra todos os cursos... a gente vai em contrapartida do que a gente tá falando... Mas pode ser criado cursos específicos né pra Educação do Campo... [...] a pessoa que tem interesse em trabalhar na escola do campo e tudo mais... ela vai direcionar pra aquele curso... (P11).

Alguns professores entrevistados fizeram a sua graduação anterior ao ano de 2010 quando a política da Educação do Campo foi incorporada ao sistema educacional estadual e foi destacada de forma mais abrangente no estado do Paraná. Já P9 e P11 declaram que comentários breves e pontuais podem ter sido ou foram realizados, respectivamente, entretanto, no momento e da forma como aconteceram não foram relevantes para a formação. Logo, é possível perceber que ter realizado o curso de 
graduação após a instituição da Educação do Campo não representa garantia da abordagem da temática.

Os professores entrevistados consideram relevante a abordagem da Educação do Campo em todas as graduações, como uma disciplina que abordasse as modalidades diferenciadas da Educação Básica, conforme sugerido pelo professor P9, pois isso possibilitaria aos professores identificar a existência de contextos diferenciados e a necessidade de tratá-los dessa forma, pois principalmente aquelas pessoas que têm um contexto de vida essencialmente urbano não conhecem a realidade do campo. Esses aspectos destacados permitem, ao sujeito que está na formação docente inicial, conhecer e caracterizar a temática, e ainda, possivelmente, se identificar com a problemática, considerando que este é um fator determinante para professores que trabalham em escolas do campo.

Entretanto, o professor P2 afirma: "[...] muitas universidades eu acredito que não terão nem um professor habilitado [...]" para ministrar sobre a temática, uma preocupação muito pertinente se houver a incorporação da Educação do Campo na grade curricular do curso de graduação, pois, se houver esta inserção, que ocorra de forma adequada, consistindo em um aprendizado relevante e significativo aos estudantes. Isso se torna possível para o professor de Ensino Superior, pois há pesquisas e produções publicadas em torno da temática.

Existem os cursos de graduação de Licenciatura em Educação do Campo que buscam ser "[...] gerador, impulsionador de um debate mais amplo sobre que Educação Básica, que organização escolar e pedagógica, que profissionais são necessários para essa realidade, continuando o debate [...]" (CALDART, 2011, p. 98) iniciado pelo documento das Diretrizes Operacionais para a Educação Básica nas Escolas do Campo, e, como o professor P11 expressa, não tem sentido a Educação do Campo ser abrangente para todos os cursos do Ensino Superior.

Faz-se, no entanto, necessário divulgar e informar, nos cursos de licenciatura em geral, sobre a modalidade de Educação do Campo presente nas escolas do campo, a fim de que os professores estejam cientes dessa especificidade de ensino da Educação Básica e para que os interessados possam posteriormente buscar especializações ou, ainda, outras formações no sentido de atender à demanda dessas escolas. Assim, consideramos relevante a inserção da temática Educação do Campo nos cursos de licenciatura de forma geral, ao mesmo tempo em que se amplia nos cursos específicos.

\subsubsection{Subcategoria 2.2: Formação continuada ofertada}

As falas dos professores apresentadas abaixo são referentes às informações e percepções sobre a formação continuada oferecida pelo NRE e pela SEED nos últimos tempos, algumas sugestões para a realização dessas formações e outros aspectos referentes à formação continuada.

[...] é uma tendência dos últimos anos... e que eu saiba não foi oferecida uma formação continuada... Eu não sei porque... deve partir lá da SEED essas formações... [...] se tivesse a formação continuada então a gente já estuda os documentos e sabe que tem que ser trabalhado de uma forma diferenciada... [...]. (P1).

[...] então na verdade a gente não tem aquela pre-pa-ra-ção... você acha:: você vê que a realidade é diferente [...] todos os professores estão inseridos na disciplina seja da cidade seja do campo não tem essa diferenciação... [...]. (P5).

[...] desde que eu comecei a trabalhar não teve nenhum curso especial assim pra Educação do Campo... não só na minha disciplina como em nenhuma outra... [...] no papel é tudo muito lindo mas na prática eu não tô vendo nada aqui que realmente agregue para a nossa formação... [...]. (P6). 
[...] é uma busca do:: profissional... Existem pós-graduações... existem cursos que a gente pode tá buscando pra fazer pra também entender e saber o que você tá trabalhando... [...] fazer essa formação inicial no começo do ano e talvez no final um fechamento né... o que a gente conseguiu de concreto... o que funcionou e o que não funcionou pra já poder planejar pro próximo melhorias né... [...]. (P7).

Parece um pouco de descaso assim com a Educação do Campo mesmo... [...] eles poderiam:: de repente faz uma formação no começo do ano... uns meses depois... [...]. (P11).

A professora P5 declara que: "[...] na verdade a gente não tem aquela pre-para-ção... você acha:: você vê que a realidade é diferente [...]" e na subcategoria 4.2, a professora diverge em relação aos outros professores, e desconsidera a necessidade em diferenciar as aulas de Ciências para o contexto urbano e do campo. Podemos observar uma incoerência no posicionamento da docente, o que pode ser fruto de uma formação que pouco deu suporte para viabilizar ações adequadas a cada contexto e/ou revela uma carência de reflexão mais aprofundada acerca da temática.

No Parecer CEE/CEB ${ }^{9} n^{\circ} 1.011 / 2010$ sobre as normas e os princípios para a implementação da Educação Básica do Campo no Sistema Estadual de Ensino do Paraná, é afirmado que a Coordenação da Educação do Campo da SEED "[...] realiza também Cursos de Formação Continuada a professores e gestores municipais, para que tais políticas ultrapassem a gestão estadual para a gestão municipal" (PARANÁ, 2010 b, p. 10). Entretanto, de acordo com os professores entrevistados, não há formação continuada específica para professores de Ciências das escolas do campo.

Conforme as Diretrizes Curriculares da Educação do Campo do Estado do Paraná (PARANÁ, 2006, p. 40): "É preciso disposição para pensar e fazer diferente", mas defendemos que somente disposição não é suficiente para fazer diferente. São fundamentais os momentos de formação continuada, momentos nos quais são possibilitados o debate de informações e a troca de experiências entre os educadores do campo. Não estão sendo oportunizados, porém, esses momentos nos quais ocorram o aperfeiçoamento e a qualificação dos professores de fato.

As experiências de formações continuadas ofertadas, segundo a professora P6, não atenderam às expectativas e agregaram minimamente os conhecimentos dos participantes. Assim, os professores devem ter dificuldade em dispor '[...] de 'ferramentas' teóricas suficientes para intervir na realidade, transformando-a e transformando também a sua prática pedagógica" (TAFFAREL; SANTOS JÚNIOR; ESCOBAR, 2010, p. 57, grifo do autor).

Nesse sentido, a formação continuada que procede da SEED apresenta-se de forma engessada, carente de inovação e originalidade e, muitas vezes, não é proposta de forma pertinente à discussão no coletivo escolar, conforme a indignação da professora P6 ao expressar seu posicionamento: "[...] no papel é tudo muito lindo... mas na prática eu não tô vendo nada aqui que realmente agregue para a nossa formação...".

Os professores salientam que a formação continuada que ocorre poderia proporcionar momentos para debate das políticas públicas sobre a Educação do Campo, conhecimento dos seus documentos balizadores, planejamento e troca de experiências. Seria relevante disponibilizar momentos aos professores para que tenham condições de reunir o coletivo das escolas do campo.

A formação continuada é um recurso que vem ao encontro da minimização das problemáticas estabelecidas no processo de ensino-aprendizagem das escolas do campo, pois "[...] é preciso romper com tratamentos ateóricos e defender a formação dos professores como aquisição, ou melhor, (re)construção de conhecimentos específicos em torno do processo ensino/aprendizagem das Ciências [...]" (CARVALHO; GILPÉREZ, 2011, p. 33).

Parecer da Câmara de Educação Básica (CEB), unidade de apoio do Conselho Estadual de Educação (CEE). 
Assim, a reunião dos pares para deliberar sobre assuntos referentes ao currículo e à prática pedagógica, a forma como a relação dialógica é estabelecida em sala de aula, propondo atividades interdisciplinares, ideias, que podem ser reconfiguradas de acordo com o contexto de cada escola, é imprescindível para estabelecer um ensino mais contextualizado e mais significativo aos estudantes do campo.

\section{CONSIDERAÇÕES FINAIS}

A investigação, de natureza qualitativa, de acordo com seu objetivo, possibilitou tecer algumas considerações sobre o ensino de Ciências e a prática pedagógica realizada pelos professores de Ciências das escolas do campo, e sobre a formação inicial e continuada desses profissionais, considerando um período definido e nos espaços escolares destacados.

A pesquisa realizada abrangeu um determinado grupo de escolas e professores, apresentando assim, limitações na generalização dos dados para diferentes regiões, pois não há homogeneidade entre as escolas do país, devido à fatores como a sua grande extensão territorial e elementos culturais diversificados. Entretanto, alguns aspectos relevantes podem ser compreendidos, a partir dos dados, e podem estimular novas investigações sobre a temática.

As percepções dos professores sobre a sua prática pedagógica se aproximam parcialmente das proposições de Freire (2015), quando consideram relevante à sua prática pedagógica conhecer o contexto e a cultura dos seus estudantes. Além disso, faz-se necessário uma reorganização dos conteúdos (SILVA, 2004), para que o professor tenha possibilidade de selecionar conteúdos curriculares relevantes para elaborar um Plano de Trabalho Docente (PTD) significativo à realidade dos estudantes do campo, pois os PTD dos professores entrevistados são elaborados de forma igualitária para escolas urbanas e do campo.

É essencial que as aulas sejam baseadas em problematizações pertinentes, contextualizadoras, para mobilizar os conhecimentos prévios, objetivando as articulações fundamentais à significação dos conteúdos, à redução da fragmentação e à sistematização do conhecimento científico (DELIZOICOV; ANGOTTI; PERNAMBUCO, 2009). Explique-se que, do contrário, conhecendo pouco o contexto dos estudantes, há uma desarticulação considerável entre o currículo abordado e realidade dos sujeitos presentes na sala de aula, dificultando a realização da prática pedagógica de forma contextualizada._

Além disso, os professores acreditam que a interdisciplinaridade pode ser uma alternativa para melhor trabalhar o conteúdo de Ciências das escolas do campo, mas apontam que essa prática não é estabelecida nas escolas por falta de momentos de encontro coletivo que propiciem o diálogo entre os professores para articular os conteúdos e planejar as atividades.

Nesse contexto, os professores de Ciências das escolas estaduais do campo do município de Toledo/PR desenvolvem atividades pedagógicas que caracterizam a busca por contextualizar os conteúdos, dentro das possibilidades que são proporcionadas aos professores, mas que se limita, em algumas situações, à ilustração de conteúdos ou à tematização da realidade (CALDART; STEDILE; DAROS, 2015), e são restritas no sentido da interdisciplinaridade, sendo focadas no ensino de Ciências, buscando a criticidade e a formação cidadã do estudante (CHASSOT, 2014).

No que se refere à formação inicial, a maior parte dos entrevistados considera relevante a abordagem dessa questão nas formações iniciais em geral para a divulgação, o conhecimento e a caracterização da temática para os graduandos..

Quanto à formação continuada, são ocasiões consideradas essenciais ao processo educativo para possibilitar o aperfeiçoamento e a qualificação dos professores. Entretanto, os momentos ofertados para esse fim não abordaram a temática da Educação do 
Campo, seja de forma geral ou específica, para professores de Ciências das escolas do campo. Apresentaram temáticas preestabelecidas, comuns entre os variados contextos presentes no Núcleo Regional de Educação. Entretanto, essa é uma ação de suporte que precisa ser viabilizada em caráter indispensável para a disseminação da política de Educação do Campo ao coletivo escolar.

É todo um cenário educacional que precisa de muitas intervenções para ser transformado. Tem-se um emaranhado de fatores, no qual a viabilidade de um fator fica dificultada ou impedida pela falta de efetivação do outro. Entretanto, como ainda são verificados muitos desafios na preparação do professor a essa sistemática de trabalho, é consequência observar muitas carências na efetivação do processo de ensino-aprendizagem inerente às escolas do campo. Isso nos mostra que a busca pela superação dos desafios ainda deve ser árdua.

Entretanto, a consideração das especificidades da Educação do Campo ainda é recente em nosso meio. Assim, poucas mudanças foram observadas para o ensino de Ciências das escolas do campo e vislumbramos uma longa trajetória para que ocorra a implementação de fato da Educação do Campo. Podemos prever um percurso de muitos estudos para a estruturação de conhecimentos e de bastante trabalho, do NRE e da SEED, no sentido de viabilizar todo o suporte teórico e técnico aos professores, aos funcionários, à direção e à equipe pedagógica das escolas do campo, e dos professores das diversas disciplinas que compõem a grade curricular, no sentido de efetivar um processo dialógico que se utilize de problematizações contextualizadas e que seja significativo aos estudantes do campo.

\section{REFERÊNCIAS}

ARROYO, M. G.; CALDART, R. S.; MOLINA, M. C. (Org.). Por uma educação do campo. Petrópolis: Vozes, 2004.

ASTOLFI, J.-P.; DEVELAY, A didática das ciências. Tradução Magda Sento Sé Fonseca. Campinas: Papirus, 1990.

BARDIN, L. Análise de conteúdo. Tradução Luís Antero Reto, Augusto Pinheiro. São Paulo: ASTOLFI, J. P.; DEVELAY, M.

BIZZO, N. Ciências: fácil ou difícil? São Paulo: Ática, 1998.

BOGDAN, R.; BIKLEN, S. K. Investigação qualitativa em educação. Porto: Porto Editora, 1994.

BRASIL. Resolução CNE/CEB n 1, de 3 de abril de 2002. Institui Diretrizes Operacionais para a Educação Básica nas Escolas do Campo. Diário Oficial da União, Brasília, DF, 9 abr. 2002. Seção 1, p. 32. Disponível em: <http://portal.mec.gov.br/index.php?option=com_doc man\&view=download\&alias=13800-rceb001-02-pdf\&ltemid=30192>. Acesso em: 21 mäio 2016.

BRICK, E. M. et al. Paulo Freire: interfaces entre ensino de ciências naturais e educação do campo. In: MOLINA, M. C. (Org.). Licenciaturas em Educação do Campo e o ensino de Ciências Naturais: desafios à promoção do trabalho docente interdisciplinar. Brasília, DF: MDA, 2014. Disponível em: <http://www.mda.gov.br/sitemda/sites/sitemda/files/user_img_248/ Livro\%20LEDOC\%20CIEMA\%20WEB.pdf>. Acesso em: 19 abr. 2015

BRITTO, N. S. Formação de professores e professoras em Educação do Campo por área de conhecimento: Ciências da Natureza e Matemática. In: MOLINA, M. C.; SÁ, L. M. (Org.). Licenciaturas em Educação do Campo: registros e reflexões a partir das experiências-piloto. Belo Horizonte: Autêntica, 2011. p. 165-178. 
. Prática docente em Ciências da Natureza na Educação do Campo. In: DUSO, L.; HOFFMANN, M. B. (Org.). Docência em Ciências e Biologia: propostas para um continuado (re)iniciar. ljuí-RS: Unijuí, 2013. p. 107-134.

. Uma trama de muitos fios: experiências, área de Ciências da Natureza e Matemática, currículo, diálogos freireanos: tecem a formação docente em Educação do Campo na UFSC. In: MOLINA, M. C. (Org.). Licenciaturas em Educação do Campo e o ensino de Ciências Naturais: desafios à promoção do trabalho docente interdisciplinar. Brasília, DF: MDA, 2014. Disponível em: <http://www.mda.gov.br/sitemda/sites/sitemda/files/user_img_248/Livro\%20 LEDOC\%20CIEMA\%20WEB.pdf>. Acesso em: 19 jun. 2017.

BRITTO, N. S.; SILVA, T. G. R. da. Educação do Campo: formação em ciências da natureza e o estudo da realidade. Educação \& Realidade, Porto Alegre, v. 40, n. 3, p. 763-784, jul./set. 2015. Disponível em: <http:// dx.doi.org/10.1590/2175-623645797>. Acesso em: 21 jun. 2016.

CALDART, R. S. Licenciatura em Educação do Campo e projeto formativo: qual o lugar da docência por área? In: MOLINA, M. C.; SÁ, L. M. (Org.). Licenciaturas em Educação do Campo: registros e reflexões a partir das experiências-piloto. Belo Horizonte: Autêntica, 2011. p. 95-121.

. Por uma educação do campo: traços de uma identidade em construção. In: KOLLING, E. J.; CERIOLI, P. R.; CALDART, R. S. (Org.). Educação do campo: identidade e políticas públicas. Brasília, DF: Articulação Nacional Por uma Educação do Campo, 2002. (Coleção Por uma educação do campo: traços, n. 4.) Disponível em: <http://www.forumeja. org.br/ec/files/Vol\%204\%20Educa\%C3\%A7\%C3\%A3o\%20B\%C3\%A1sica\%20do\%20Campo. pdf>. Acesso em: 23 abr. 2016.

CALDART, R. S.; STEDILE, M. E.; DAROS, D. (Org.). Caminhos para a transformação da escola 2. São Paulo: Expressão Popular, 2015.

CARVALHO, A. M. P. de. Uma metodologia de pesquisa para estudar os processos de ensino e aprendizagem em salas de aula. In: SANTOS, F. M. T. dos; GRECA, I. M. 2. ed. rev. A pesquisa em ensino de ciências no Brasil e suas metodologias. ljuí-RS: Unijuí, 2011. p. 13-48.

CARVALHO, A. M. P. de; GIL-PÉREZ, D. Formação de professores em Ciências: tendências e inovações. 10. ed. São Paulo: Cortez, 2011.

CHASSOT, A. Alfabetização científica: questões e desafios para a educação. 6. ed. Ijuí-RS: Unijuí, 2014.

CHAUÍ, M. Convite à filosofia. São Paulo: Ática, 2000.

CUNHA, M. B. da. A percepção de Ciência e Tecnologia dos estudantes de Ensino Médio e a divulgação científica. 2009. Tese (Doutorado em Educação)- Faculdade de Educação, Universidade de São Paulo, São Paulo, 2009. Disponível em: <http://www.teses.usp.br/teses/disponiveis/48/48134/tde-02032010-091909/pt-br.php>. Acesso em: 23 out. 2016.

DELIZOICOV, D.; ANGOTTI, J. A.; PERNAMBUCO, M. M. O ensino de Ciências: fundamentos e métodos. São Paulo: Cortez, 2009.

FREIRE, P. Extensão ou comunicação? Traução Rosisca Darcy de Oliveira. 10. ed. Rio de Janeiro: Paz e Terra, 1977.

Pedagogia da autonomia: saberes necessários à prática educativa. 52. ed. Rio de Janeiro: Paz e Terra, 2015. 
KRASILCHIK, M. Reformas e realidade: o caso do ensino das ciências. São Paulo em Perspectiva, v. 14, n. 1, p. 85-93, 2000. Disponível em: <http://www.scielo.br/pdf/spp/v14n1/9805. pdf>. Acesso em: 3 jun. 2016.

LURIA, A. R. Desenvolvimento cognitivo: seus fundamentos culturais e sociais. Tradução Fernando Limongeli Gurgueira. 7. ed. São Paulo: Ícone, 2013.

MINAYO, M. C. de S. Pesquisa social: teoria, método e criatividade. 29. ed. Petrópolis: Vozes, 2010.

MIZUKAMI, M. da G. N. Aprendizagem da docência: professores formadores. Revista E-Curriculum, São Paulo, v. 1, n. 1, dez./jul. 2005/2006. Disponível em: <http://revistas.pucsp.br/ index.php/curriculum/article/view/3106>. Acesso em: 15 jun. 2016.

PARANÁ. Instrução Conjunta $n^{\circ}$ 001/2010 - SEED/SUED/SUDE. Orientação sobre estratégias para elaboração e implementação de um plano de trabalho integrado voltado a Educação do Campo. Secretario de Estado da Educação. Curitiba, 29 nov. 2010a. Disponível em: <http://www.educacao.pr.gov.br/arquivos/File/instrucoes/instrucao_conjunta0012010.pdf>.

Acesso em: 1 maio 2016.

Parecer CEE/CEB no 1011/2010, aprovado em 6 de outubro de 2010. Consulta sobre as Normas e princípios para a implementação da Educação Básica do Campo no Sistema Estadual de Ensino do Paraná, bem como do processo de definição da identidade das Escolas do Campo. Conselho Estadual de Educação. Curitiba, 6 out. 2010b. Disponível em: <http:// www.cee.pr.gov.br/arquivos/File/ pdf/Pareceres2010/CEB/pa_ceb_1011_10.pdf>. Acesso em: 1 maio 2016.

Resolução $n^{0} 4.783$, de 28 de outubro de 2010. Institui a Educação do Campo como Política Pública Educacional com vistas à garantia e à qualificação do atendimento escolar aos diferentes sujeitos do campo, nos diferentes níveis e modalidades de ensino da Educação Básica. Diário Oficial da Casa Civil. Curitiba, 18 nov. 2010c. Disponível em: <http://www.legislacao.pr.gov.br/legislacao/pesquisarAto.do? action=exibir\&codAto=69377\&codTipoAto=\&tipoVisualizacao=original>. Acesso em: 30 abr. 2016.

Secretaria de Estado da Educação. Diretrizes Curriculares da Educação Básica de Ciências. Curitiba: Seed/DEB-PR, 2008.

Secretaria de Estado da Educação. Diretrizes Curriculares da Educação do Campo. Curitiba: Seed/SUED-PR, 2006.

POZO, J. I.; CRESPO, M. Á. G. A aprendizagem e o ensino de Ciências: do conhecimento cotidiano ao conhecimento científico. Tradução Naila Freitas. 5. ed. Porto Alegre: Artmed, 2009.

SANTOS, W. L. P. dos; SCHNETZLER, R. P. Educação em Química: compromisso com a cidadania. 3. ed. ljuí-RS: Unijuí, 2003.

SCHNETZLER, R. P. Construção do conhecimento e ensino de Ciências. Em Aberto, Brasília, v. 11, n. 55, p. 17-22, jul./set. 1992.

SILVA, A. F. G. da. A construção do currículo na perspectiva popular crítica: das falas significativas às práticas contextualizadas. 2004. Tese (Doutorado em Educação)- Pontifícia Universidade Católica de São Paulo, São Paulo, 2004. Disponível em: <http://www.educadores. diaadia.pr.gov.br/arquivos/File/outubro2011/quimica_artigos/tese_gouvea3.pdf >. Acesso em: 7 jan. 2017.

STRECK, D.; REDIN, E.; ZITKOSKI, J. J. (Org.). Dicionário de Paulo Freire. Belo Horizonte: Autêntica Editora, 2008. 
TAFFAREL, C. N. Z.; SANTOS JÚNIOR, C. de L.; ESCOBAR, M. O. Cadernos didáticos sobre Educação do Campo. Salvador: UFBA/MECq, 2010.

THOMPSON, P. A voz do passado: história real. 3. ed. Tradução Lólio Lourenço de Oliveira. Rio de Janeiro: Paz e Terra, 1992.

WARTHA, E. J.; SILVA, E. L. da; BEJARANO, N. R. R. Cotidiano e contextualização no ensino de Química. Química Nova na Escola, v. 35, n. 2, p. 84-91, maio 2013. Disponível em: <http:// qnesc.sbq.org.br/ online/qnesc35_2/04-CCD-151-12.pdf>. Acesso em: 16 jul. 2015. 